International Journal of Biology, Pharmacy and Allied Sciences (IJBPAS) 'A Bridge Betueen Caboratory and QRendor'

WwW.ijbpas.com

\title{
ZOOPLANKTON DIVERSITY FROM GANGAPUR DAM, NASHIK,
} MAHARASHTRA

\section{D.G.KAPADNIS $^{1^{*}}$ AND AGNES JOHN KHARAT $^{2}$}

MGV's Arts, Science \& Commerce College Surgana, Dist. Nashik

*Corresponding Author: Dr. D.G.Kapadnis: E Mail: nitinhira31@gmail.com

Received $10^{\text {th }}$ June 2021; Revised $11^{\text {th }}$ July 2021; Accepted $20^{\text {th }}$ Aug. 2021; Available online 15 ${ }^{\text {th }}$ Jan. $_{2022}$

https://doi.org/10.31032/IJBPAS/2022/11.1.1027

\begin{abstract}
Planktons play vital role in the energy transmission at secondary level in any aquatic ecosystem. Planktons are indicators of pollution. Zooplankton diversity along with physic-chemical factors like temperature, $\mathrm{pH}, \mathrm{EC}$, Turbidity, TDS, DO, BOD and COD was studied from Gangapur Dam, Nashik, Maharashtra. Present investigation has recorded 40 species of Rotifera, 10 species of Copepodes, 14 species of Cladocera and 8 species of Ostracoda. It is observed that throughout the year Rotifer community dominates followed by cladocera, Copepoda and ostracopoda respectively. Total count of Zooplanktons per liter was recorded highest in the month of May. Physico-chemical parameters along with rainfall show peculiar effect on zooplankton diversity. Along with rainfall quality of runoff influx mainly affects the zooplankton diversity in an aquatic ecosystem.
\end{abstract}

\section{Keywords: Zooplanktons, Bio-indicators, Gangapur Dam}

\section{INTRODUCTION:}

Godavari is the longest river of Peninsular India that flows through Nashik district. Gangapur Dam is an earthfill dam on the Godavari river near Nashik in Maharashtra. The dam is one of the oldest dam in Maharashtra that provides drinking water to the Nahshik population. It is located at $20.0260565^{\circ} \mathrm{N}$ latitude and $73.6671498^{\circ} \mathrm{E}$ longitude. The dam covers the catchment area of $357.4 \mathrm{~km}^{2}$. Water level in the dam depends mainly on the rainfall. Basically this dam was constructed for the purpose of irrigation.

South-west monsoon season starts from 
June to September. Except monsoon season the climate of Nashik District is generally dry throughout the year. October and November constitute the post-monsoon season. Winter season begins from December to February which is followed by summer season from March to May. According to Koppen climate classification the city has a semi-arid climate with $42.5^{\circ} \mathrm{C}$ maximum summer temperature, $5.0^{\circ} \mathrm{C}$ minimum winter temperature, $43 \%$ to $62 \%$ relative humidity and $500 \mathrm{~mm}$ to 3400 $\mathrm{mm}$ normal annual rainfall in the district.

Nashik city is one of the fastest growing industrial city in Maharashtra. Earlier Nashik was famous for its cold climate but now a day's temperature increase, air and water pollution are the main penalties of urbanization and fast growing industrialization. Agricultural activities like recurrent tilling, chemical fertilizers and pesticides that passed to the aquatic ecosystem along with agricultural runoff and flow in the reservoir along with domestic sewage also add up in the water pollution.

Planktons forms the basic level of food chain. They are microscopic group of organisms including both plants and animals (Sommer, 1994). According to Keller et al., 2008, planktons are important bio-indicators of water quality. They play significant role in biogeochemical cycles like methanogenesis remineralization, nitrification, denitrification and carbon cycle. Planktons play major role in the food chain of many aquatic animals. Planktons are the source of life for most of aquatic organism especially in their larval stages. Many fish species depend on it as a food source after absorbance of yolk sac. It has been professed from long time back that Planktons are the major resource of nourishment for fish larvae. Planktons play vital role in the energy transmission at secondary level in any aquatic ecosystem.

Zooplanktons community include Rotifera, Copepoda, Cladocera and Ostracoda. The relative abundance of each other is influential over community structure, which depends upon the relative range of tolerance towards changing seasonal physic-chemical properties of water as well as relative abundance of resource available. Planktons feeding on same resource in a homogenous environment cannot co-exist because of competitive exclusion (Hutchinson 1961). Planktons are bioindicators of the pollution. Abundance of Rotaria and Asplanchuna in water is indicator of water pollution (Gholap, 2014). Few members of rotifer when present in abundant number is indication of eutrophication of lakes, they are Brachionus forficula, Brachionus nilsoni, and Trichocerca 
sp (Azma Hanim Ismail et al, 2016). In a study of lake Parque Atalaia in America, Rotifera diversity was markedly low during dry season under the influence of pollution of water by inlet of domestic sewage (Neves et al., 2003).

\section{MATERIALS AND METHODS:}

For the current review, water tests were gathered from four unique destinations of Gangapur dam haphazardly. The water samples were gathered by norms and method for assessment of water and waste water American Public Health Association (APHA1989) and seventeenth version of Beuro of Indian standard strategies for Sampling and Test (Physical and Chemical) for water and waste water (BIS-3025) as a manual for examination.

Temperature and $\mathrm{pH}$ of water was recorded at the time of sample collection. Temperature is measured with help of glass thermometer. Temperature is recorded after two hours of sunrise concurrently with water sample collection. Test water collection time is retained unchanged throughout the year. Other physico-chemical parameters like turbidity, TDS (Total Dissolved Solids), OD, BOD etc. were analysed in the laboratory as per procedure mentioned in USGS manual and EPA government manuals (USGS Manual and eps.gov) (epa.gov manual). Zooplanktons were gathered with 80 cross section size net and 50 liters of water was sifted through net. The water samples containing planktons were carefully transferred to the bottle and brought to the laboratory without disturbance. Samples were collected twice in a month from all four stations of dam, for period of 12 months from January 2020 to December 2020. The samples were collected during morning hours. Planktons were observed under a light microscope and identified by using standard Key, other literature (APHA, 1998; Dhanpati 2000, Permak 1989 ).

\section{RESULTS AND DISCUSSION:}

Water temperature was observed highest in May and least in December (Table 1). Turbidity and Electric conductivity (EC) increases with the accumulation of rainfall in rainy season. Therefore both of these parameters are more in month of August and March which correlates with maxima of rainfall (Table 1). $\mathrm{pH}$ diminishes with expansion of downpour water rainstorm yet despite the fact that it never reach under 7 or acidic level that is the vacillation is inside the range of fundamental $\mathrm{pH}$. During summer season at hotter temperature the $\mathrm{pH}$ is high (Table 1). Turbidity increases in the rainy season showing peak in month of August (Table 1). Dissolved Oxygen (DO) follows the example of consolidated impact of temperature and precipitation. Dissolved oxygen decreases 
in summer season while the monsoon rain enhances concentration of DO in water (Table 1). Biological Oxygen Demand (BOD) and Chemical Oxygen Demand (COD) however follow a similar example yet too low upsides of BOD over COD demonstrates the degree of natural contamination in the supply from homegrown sewage, human mediation and that too in summer season when amount of water in repository was relatively less (Table 1).

\section{Among zooplanktons Rotifera,} Copepoda, Cladocera and Ostracoda are recorded from the study area. In summer season especially in the month of May all the zooplanktons counted highest in number that is organisms per litter. In winter season that is in December organisms count is less (Table 2). Zooplankton count lowered with the arrival of rainfall in the month of June due to influx of rainwater. The quantity of rainfall and the quality of inlet water through agriculture runoff along with temperature are the important factors that directly or indirectly govern all other abiotic factors considered here like total TDS, $\mathrm{pH}$ of water and BOD and COD. In summer season Rotifera, Copepoda, Cladocera and Ostracoda predominate in terms of quantity and diversity than other seasons.

Rotifera dominates the zooplankton community. 40 species of Rotifera are recorded from collected water samples (Table 3). Brachinus species dominate among the Rotifera. Among zooplanktons 10 species of Copepodes (Table 3), 14 Cladocera (Table 3), and 08 species of Ostracoda (Table 3), are recorded from the collected samples. It has been observed that rotifera dominated the community throughout the year pursued by Ostracoda, Copepoda and least is Cladocera. Growth rate of inhabitants may be highest in summer season especially in the month of May which follow high temperature and count is lowest in winter season during November and December. Thus temperature is the significant physical factors that rule the population either directly by affecting the population growth rate or indirectly by affecting other physicchemical parameters. Along with rainfall quality of runoff influx mainly affects the zooplankton diversity in an aquatic ecosystem.

Rotaria and Asplanchuna were found relatively abundant in collected water sample which is indicator of water pollution. Eutrophication indicators Brachionus forficula, Brachionus nilsoni, and Trichocerca sp are also recorded from the collected water examples. 
Table 1: Physico-chemical Parameters of water samples from Gangapur Dam, Nashik:

\begin{tabular}{|c|c|c|c|c|c|c|c|c|}
\hline Month & Temperature & pH & EC & Turbidity & TDS & DO & BOD & COD \\
\hline January & 23 & 7.9 & 461.44 & 7.7 & 335 & 4.04 & 4.47 & 36.59 \\
\hline February & 20 & 7.8 & 488.17 & 8.9 & 354 & 4.50 & 3.82 & 31.35 \\
\hline March & 26 & 7.6 & 552.88 & 9.3 & 400 & 4.72 & 8.30 & 67.68 \\
\hline April & 27 & 7.9 & 541.78 & 8.5 & 392 & 4.32 & 5.02 & 41.09 \\
\hline May & 32 & 7.5 & 482.62 & 8.3 & 349 & 3.90 & 4.86 & 39.72 \\
\hline June & 29 & 7.7 & 579.21 & 9.6 & 420 & 5.38 & 3.58 & 29.35 \\
\hline July & 28 & 7.1 & 633.72 & 12.6 & 459 & 6.01 & 3.02 & 24.79 \\
\hline August & 23 & 7.1 & 769.26 & 15.6 & 558 & 7.53 & 2.31 & 19.04 \\
\hline September & 26 & 7.3 & 729.10 & 15.0 & 528 & 7.15 & 1.15 & 9.62 \\
\hline October & 22 & 7.5 & 695.07 & 13.6 & 504 & 6.66 & 1.39 & 11.59 \\
\hline November & 21 & 7.6 & 646.28 & 11.7 & 468 & 5.75 & 2.23 & 18.40 \\
\hline December & 19 & 7.8 & 538.50 & 11.3 & 364 & 4.97 & 2.93 & 24.02 \\
\hline
\end{tabular}

Table 2: Total Count of Zooplanktons recorded from the water samples of Gangapur Dam (Organisms / Lit.):

\begin{tabular}{|c|c|c|c|c|}
\hline Month & Rotifera & Copepoda & Cladocera & Ostracoda \\
\hline January & 103 & 42 & 37 & 36 \\
\hline February & 123 & 47 & 42 & 30 \\
\hline March & 136 & 41 & 55 & 31 \\
\hline April & 142 & 62 & 79 & 42 \\
\hline May & 158 & 89 & 62 & 58 \\
\hline June & 153 & 70 & 52 & 47 \\
\hline July & 139 & 59 & 32 & 38 \\
\hline August & 111 & 45 & 49 & 21 \\
\hline September & 116 & 64 & 56 & 36 \\
\hline October & 121 & 63 & 55 & 40 \\
\hline November & 133 & 51 & 45 & 41 \\
\hline December & 106 & 49 & 43 & 40 \\
\hline
\end{tabular}

Table 3: List of Zooplanktons observed from the water samples of Gangapur Dam, Nashik

\begin{tabular}{|c|c|c|c|}
\hline \multicolumn{4}{|c|}{ List of Rotifers } \\
\hline Asplanchna sp. & Brachionus angularis & Brachionus ureceolaris & Brachionus calyciflorus \\
\hline Brachionus diversicornis & Brachionus folculus & Brachionus falcatus & Brancionous calciflorus \\
\hline Brachionus quadridentatus & Brachionus caudatus & Brachionus forficula & Cephalodella exigna \\
\hline Colurella adriatica & Cephalodella forficula & Dicranophorus dolerus & Euchlanis dilatata \\
\hline Epiphanes clovulata & Filinia longiseta & Filinia opoliensis & Keratella tropica \\
\hline Kertella valga & Keratella procura & Keratella cochlearis & Lecane bidentata \\
\hline Lecane bulla & lecane depressa & Lecane pyriformis & Lepadella ovalis \\
\hline Lepadella patella & Monostyella sp. & Notholca acuminata & Notomata copeus \\
\hline Pseudoharringia similis & Proales decipiens & Rotaria spp & Trichocerca tigris \\
\hline Tripleuchlanis spp & Testudinella patina & Testudinella sp. & Filina spp. \\
\hline \multicolumn{4}{|c|}{ List of Copepoda } \\
\hline Cyclops sp. & Cyclops viridis & Diaptamus spp. & Eudiaptomus gracilis \\
\hline Heliodiaptomus contortus & Mesocyclop sps & Mesocyclops leuckarti & Megacyclops sp. \\
\hline Nauplius larvae & Paracyclops fimbriatus & & \\
\hline \multicolumn{4}{|c|}{ List of Cladocera } \\
\hline Alona guttata Sars & Bosmina longirostris & Biapertura Moina mircura & Biapertura affinis (Leydig) \\
\hline Cypris Flurcularia & Ceriodaphnia pulchella Sars & Daphnia cucullata Sars & Daphnia sp \\
\hline $\begin{array}{c}\text { Grimaldina brazzai } \\
\text { (Richard) }\end{array}$ & Ilyocryptus sordidus (Lievin) & Macrothrix goeldii (Richard) & Macrothrix spinosa (King) \\
\hline Scapholeberis kingi Sars & Trophocyclops & & \\
\hline \multicolumn{4}{|c|}{ List of Ostracoda } \\
\hline Candocypris spp. & Candona Centrocypris & Cyprides Cyprinotus & Cypris spp. \\
\hline Darwinula Ilyocypris & Limnocythere & Metacypris & Potamocypris \\
\hline
\end{tabular}




\section{CONCLUSION:}

Present investigation has recorded 40 species of Rotifera, 10 species of Copepodes, 14 species of Cladocera and 8 species of Ostracoda. It is observed that throughout the year Rotifer community dominates followed by cladocera, Copepoda and ostracopoda respectively. Total count of Zooplanktons per liter was recorded highest in the month of May. Physico-chemical parameters along with rainfall show peculiar effect on zooplankton diversity.

\section{Acknowledgement:}

Authors are grateful to Principal of MGV's Arts, Science and Commerce College Surgana for endowing essential laboratory amenities required to complete present investigation.

\section{REFERENCES:}

[1] APHA, AWWA and WPCF Standard methods for the examination of Water and Wastewater Eds. A.D. Eaton, L.S. Cleseri and A.I. Greenberg, 20th ed., American Public Health Association, 1998

[2] Azma Hanim Ismail and Anis Amalina Mohd Adnan (2016) Zooplankton Composition and Abundance as Indicators of Eutrophication in Two Small Man-made Lakes, Trop Life Sci Res. 2016 Nov; 27(supp1): 31-38.
[3] Beuro of Indian standard methods of Sampling and Test (Physical and Chemical) for water and waste water (IS-3025)

[4] Dhanpati, M.V.S.S.S (2000) "Taxonomic notes on the rotifers from India from 1989 - 2000" Indian Association of Aquatic Biologist (IAAB), Hyderabad.

[5] Gholap Avinash B (2014) Species diversity indices of zooplankton from Sadatpur reservoir, Ahmednagar, Maharashtra, Annals of Biological Research, 2014, 5 (4):58-61.

[6] http://water.usgs.gov/owq/FieldManual /chapter4/html/Ch4 contents.html

[7] http://www.epa.gov/region6/qa/qadevto ols/mod5 sops/groundwater/sampling/r 1 _gw sampling.pdf.

[8] Hutchinson GE (1961) The paradox of the plankton. American Naturalist 95:137-145.

[9] Keller, B., J. Wolinska, M. Manka, P. Spaak. (2008). Philosophical Transactions of the Royal Society B: Biological Sciences, 363, 2943-2952

[10] Neves IF, Rocha O, Roche KF, Pinto AA (2003) Zooplankton community structure of two marginal lakes of the River Cuiabá (Mato Grosso, Brazil) with analysis of Rotifera and 
Cladocera diversity. Braz J Biol. 2003 May;63(2):329-43. Epub 2003 Aug 15.

[11] Permak R. W. (1989) "Freshwater invertebrates of the United States" 3rd edition John wiley and sons New York.

[12] Sommer. U. (1994). Planktologie. Springer, 274pp

[13] G. S. Sajja, M. Mustafa, K. Phasinam, K. Kaliyaperumal, R. J. M. Ventayen and T. Kassanuk, "Towards Application of Machine Learning in Classification and Prediction of Heart Disease," 2021 Second International Conference on Electronics and Sustainable Communication Systems (ICESC), 2021， pp. 1664-1669, doi:10.1109/ICESC51422.2021.9532 $\underline{940}$

[14] Veluri, R., Patra, I., Naved, M., Prasad, V., Arcinas, M., Beram, S., \& Raghuvanshi, A. (2021). Learning analytics using deep learning techniques for efficiently managing educational institutes. Materials Today: Proceedings. https://doi.org/10.1016/j.matpr.2021.1 $\underline{1.416}$

[15] C.M. Thakar, S.S. Parkhe, A. Jain et al., 3d Printing: Basic principles and applications, Materials Today:

Proceedings, https://doi.org/10.1016/j. matpr.2021.06.272 